\title{
Study of Genetic Divergence in Soyabean (Glycine max. (L.) Merrill) Germplasm
}

\author{
Rohitash Sharma* and Gaibriyal M. Lal \\ Department of Genetics and Plant Breeding, Naini Agricultural Institute, Sam Higginbottom \\ University of Agriculture, Technology and Sciences, Prayagraj (Allahabad)- 211007, \\ Uttar Pradesh, India \\ *Corresponding author
}

A B S T R A C T

\section{Keywords}

Soybean, Heritability, Genetic advance, $\mathrm{D}^{2}$ statistics, Cluster analysis

\section{Article Info}

\section{Accepted:}

18 August 2020

Available Online:

10 September 2020
Genetic divergence of 40 soybean genotypes was studied for eleven quantitative traits using Mahalanobis's D ${ }^{2}$ statistics during Kharif-2019 in Randomized Block Design with three replications. Analysis of Variance showed significant differences for all characters under study at $1 \%$ and 5\% Level of Significance. High estimates of GCV and PCV were observed for number of pods per plant followed by seed yield per plant. High heritability coupled with high genetic advance was recorded for plant height followed by test weight. Based on the relative magnitude of D2 values, the genotypes were grouped into nine clusters. Cluster III constituted maximum number of genotypes with 19 genotypes followed by cluster I. Maximum intra-cluster distance was found in cluster III followed by cluster II. Maximum inter-cluster distance (D2) was observed between cluster III and V. Test weight contributed maximum towards genetic divergence. Based on inter cluster distances and Per se performance, the genotypes TNAU 20051, MAUS 128 and KB 17 with test weight traits should be given top priority during selection of the genetically divergent parents in future breeding program.

\section{Introduction}

Soybean (Glycine max (L.) Merrill) popularly known as "Miracle crop" is a member of family Leguminosae and is widely used as oilseed crop. Soybean is a self-pollinated crop having chromosome number of $2 \mathrm{n}=40$. Soybean is a very good source for both protein and oil as it has protein content of 40 to $42 \%$ which is highest among food crops and 18 to $22 \%$ oil content comprising $85 \%$ unsaturated fatty acids and free from cholesterol, therefore it is highly desirable in the human diet (Antalina et al., 1999). Global area under soybean cultivation is around 124.90 million hectares and 350.0million ton production where USA, Brazil, Argentina, China and India accounts more than $85 \%$ acreages and $88.5 \%$ of production among all soybean growing countries (FAO, 2017-18). India ranks 4th in terms of soybean area but 5th in terms of production after USA, Brazil, Argentina and China, however productivity of soybean in India is very low (1.04 t/ha) as 
compared to average global productivity (2.9 $\mathrm{t} / \mathrm{ha}$ ). During 2017-18 the production of soybean in India was 10.98 million tons from 10.47 million-hectare area with productivity of $1.04 \mathrm{t} / \mathrm{ha}$ (Directorate of Economics \& Statistics, DAC\&FW). The major soybean growing states in India are Madhya Pradesh, Maharashtra and Rajasthan which accounts around $93 \%$ in terms of both acreages and production among all soybean growing states. Area under soybean in Uttar Pradesh (UP) is currently very low and so is the case of productivity. Looking to very low productivity of soybean in India, it's a need to improve its productivity by both genetical and agronomical means where genetical means of improving productivity of any crops play a major role.

Genetically diverse parent is a pre-requisite to improve the chances of selecting better segregants for various characters. When such parents are utilized in hybridization program, they are likely to produce high heterotic effect and wide spectrum of variability (Barhet al., 2014). The assessment of genetic diversity is important not only for crop improvement but also for efficient management and conservation of germplasm resources. Keeping this in view, the present investigation was carried out to assess the nature and magnitude of genetic diversity in soybean germplasm.

\section{Materials and Methods}

The experiment was carried out in the Field Experimentation Centre, Department of Genetics and Plant Breeding, Naini Agricultural Institute, Sam Higginbottom University of Agriculture, Technology and Sciences, Prayagraj, U.P, India. The experimental materials for the present study consisted of 40 genotypes of Soybean including 1 local check was procured from Indian Institute of Soybean Research (IISR),
Indore. The seeds of all soybean germplasm were planted in experimental field in a Randomized Block Design (RBD) trial with three replications. All necessary precautions were taken to maintain uniform plant population in each treatment and replications. All the recommended package of practices was followed along with necessary prophylactic plant protection measures to raise a good crop. Observations were recorded at different stage of plant growth and at harvest. The data was subjected to statistical analysis. The variability was estimated as per procedure for analysis of variance suggested by Fischer (1936), Phenotypic Coefficient of Variance (PCV) and Genotypic Coefficient of Variance GCV were calculated using formula given by Burton (1952), heritability in broad sense $\left(\mathrm{h}^{2}\right)$ as suggested by Burton and De Vane (1953), genetic advance i.e., the expected genetic gain were calculated by using the procedure given by Johnson et al., (1955), and genetic divergence was calculated by using $\mathrm{D}^{2}$ Statistics given by Mahalonobis (1936).

\section{Results and Discussion}

Analysis of variance showed significant differences among 40 soybean genotypes for all the characters under study. Similar variations in soybean have been also reported by Karad et al., in 2005. The Phenotypic Coefficient of Variation were higher in magnitude than the Genotypic Coefficient of Variation for all the characters and the difference between PCV and GCV was low for most of the characters, this indicates less influence of environment in the expression of these characters in soybean germplasm. Similar information was also reported in soybean by Chandrawat et al., in 2017. The magnitude of GCV and PCV was highest for no. of pods per plant (35.11\&35.58). The heritability estimates were found to be high (more than 70\%) for all the characters except 
numbers of seeds per pod (65.00). High heritability coupled with high genetic advance as per cent mean $(>20)$ in the present genotypes were recorded for plant height $(98.60 \%$ and $49.61 \%)$ indicating predominance of additive gene effects and the possibilities of effective selection for the improvement of these characters (Fig. 1 and 2).

Table.1 Area, production and Productivity of soybean during 2017-2018

\begin{tabular}{|l|c|c|c|}
\hline Particulars & Area (Mha) & $\begin{array}{c}\text { Production } \\
\text { (Mt) }\end{array}$ & $\begin{array}{c}\text { Productivity } \\
\text { (t/ha) }\end{array}$ \\
\hline World & 124.90 & 348.71 & 2.79 \\
\hline India & 10.47 & 10.98 & 1.04 \\
\hline
\end{tabular}

Source: FAO Statistics, 2017-18

Table.2 List of soybean genotypes used in the present investigation

\begin{tabular}{|c|c|c|c|c|c|c|c|}
\hline S. No. & $\begin{array}{l}\text { Name of } \\
\text { Genotype }\end{array}$ & $\begin{array}{c}\text { S. } \\
\text { No. }\end{array}$ & $\begin{array}{l}\text { Name of } \\
\text { Genotype }\end{array}$ & $\begin{array}{c}\text { S. } \\
\text { No. }\end{array}$ & $\begin{array}{l}\text { Name of } \\
\text { Genotype }\end{array}$ & $\begin{array}{c}\text { S. } \\
\text { No. }\end{array}$ & Name of Genotype \\
\hline 1. & NRC 37 & 11. & EC 15961 & 21. & UPSM 1087 & 31. & SL 432 \\
\hline 2. & EC 251541 & 12. & JSM 245 & 22. & SL 752 & 32. & LEE 75 \\
\hline 3. & UPSM 55 & 13. & SQL 37 & 23. & NRC 801 & 33. & TG 5404E \\
\hline 4. & PK 258 & 14. & JSM 195 & 24. & TNAU 20051 & 34. & MACS 1259 \\
\hline 5. & RKS 54 & 15. & PK 701 & 25. & PS 1467 & 35. & PK 1038 \\
\hline 6. & UGM 75 & 16. & EC 251682 & 26. & PS 1336 & 36. & RKS 48 \\
\hline 7. & JSM 232 & 17. & JS 9631 & 27. & PS 1475 & 37. & TNAU 2024 \\
\hline 8. & EC 381884 & 18. & KB 17 & 28. & JSM 222 & 38. & MAUS 128 \\
\hline 9. & NRC 2006M & 19. & UPSL 152 & 29. & SL 744 & 39. & G 91 \\
\hline 10. & UPSM 57 & 20. & UPSM 77 & 30. & MACS 171 & 40. & JS 2029 (Check) \\
\hline
\end{tabular}

Table.3 Analysis of Variance for different quantitative characters in soybean genotypes

\begin{tabular}{|l|c|c|c|}
\hline \multirow{2}{*}{ Characters } & \multicolumn{3}{|c|}{ Mean sum of squares } \\
\hline Days to 50\% flowering & Replication(d. f.= 2) & Treatments (d. f.= 39) & Error (d. f.= 78) \\
\hline Plant height & 0.433 & $44.294^{* *}$ & $\mathbf{1 . 3 2 2}$ \\
\hline No. of primary branches & 4.662 & $809.366^{* *}$ & $\mathbf{3 . 9 3 5}$ \\
\hline No. of nodes per plant & 0.012 & $2.652^{* *}$ & $\mathbf{0 . 0 3 0}$ \\
\hline No of clusters per plant & 0.026 & $11.122^{* *}$ & $\mathbf{0 . 0 9 5}$ \\
\hline No. of pods per plant & 0.156 & $2.916^{* *}$ & $\mathbf{0 . 1 1 7}$ \\
\hline No. of seeds per pod & 2.561 & $906.717^{* *}$ & $\mathbf{8 . 1 1 6}$ \\
\hline Biological yield & 0.009 & $0.115^{* *}$ & $\mathbf{0 . 0 1 7}$ \\
\hline Harvest index & 6.939 & $90.952^{* *}$ & $\mathbf{3 . 9 5 3}$ \\
\hline Test weight & 7.252 & $69.992^{* *}$ & $\mathbf{5 . 2 5 3}$ \\
\hline Seed yield per plant & 0.231 & $15.858^{* *}$ & $\mathbf{0 . 0 9}$ \\
\hline
\end{tabular}

*Indicates significant at $5 \%$ level of significance

** Indicates significant at $1 \%$ level of significance 
Table 4 Estimation of genetic variability parameters for different quantitative characters

\begin{tabular}{|c|l|c|c|c|c|c|}
\hline S.No. & Characters & GCV & PCV & $\mathbf{H}^{\mathbf{2}}(\mathbf{\%})$ & GA (5\%) & GA as \% of mean (5\%) \\
\hline $\mathbf{1}$ & Days to 50\% flowering & 8.22 & 8.59 & 91.50 & 7.46 & 16.19 \\
\hline $\mathbf{2}$ & Plant height (cm) & 24.26 & 24.44 & 98.60 & 33.51 & 49.61 \\
\hline $\mathbf{3}$ & No. of primary branches & 26.49 & 26.94 & 96.70 & 1.89 & 53.64 \\
\hline $\mathbf{4}$ & No. of nodes per plant & 16.07 & 16.27 & 97.50 & 3.90 & 32.68 \\
\hline $\mathbf{5}$ & No. ofclusters per plant & 15.15 & 16.08 & 88.80 & 1.88 & 29.41 \\
\hline $\mathbf{6}$ & No. of pods per plant & 35.11 & 35.58 & 97.40 & 35.18 & 71.36 \\
\hline $\mathbf{7}$ & No. of seeds per pod & 7.50 & 9.31 & 65.00 & 0.30 & 12.45 \\
\hline $\mathbf{8}$ & Biological yield & 22.67 & 24.16 & 88.00 & 10.41 & 43.09 \\
\hline $\mathbf{9}$ & Harvest Index & 21.35 & 23.81 & 80.40 & 8.58 & 39.45 \\
\hline $\mathbf{1 0}$ & Test weight & 22.59 & 22.78 & 98.30 & 4.68 & 46.14 \\
\hline $\mathbf{1 1}$ & Seed yield per plant & 28.13 & 28.56 & 97.00 & 2.90 & 57.09 \\
\hline
\end{tabular}

Table.5 Distribution of genotypes into different clusters

\begin{tabular}{|c|c|l|}
\hline Cluster & Number of genotypes & \multicolumn{1}{|c|}{ Genotypes } \\
\hline I & 11 & $\begin{array}{l}\text { NRC 37, PK 258, EC 15961, PK 701, SL 752, MACS 171, SL } \\
\text { 432, LEE 75, PK 1038, RKS 48, G 91 }\end{array}$ \\
\hline II & 4 & UPSM 57, UPSM 77, UPSM 1087, UPSL 152 \\
\hline III & 19 & UPSM 55, RKS 54, UGM 75, JSM 232, EC 381884, NRC 2006M, \\
& & JSM 245, JSM 195, JS 9631, KB 17, NRC 801, PS 1467, PS 1336, \\
& & PS 1475, JSM 222, SL 744, TG 5404E, MACS 1259, TNAU 2024 \\
\hline IV & 1 & SQL 37 \\
\hline V & 1 & MAUS 128 \\
\hline VI & 1 & EC 251682 \\
\hline VII & 1 & TNAU 20051 \\
\hline VIII & 1 & EC 251541 \\
\hline IX & 1 & JS 2029 \\
\hline & & \\
\hline
\end{tabular}

Table.6 Cluster mean value for 11 characters in soybean genotypes

\begin{tabular}{|c|c|c|c|c|c|c|c|c|c|c|c|}
\hline $\begin{array}{c}\text { Cluste } \\
\mathbf{r}\end{array}$ & $\begin{array}{c}\text { Days to } \\
50 \% \\
\text { flowering }\end{array}$ & $\begin{array}{c}\text { Plant } \\
\text { height } \\
(\mathbf{c m})\end{array}$ & $\begin{array}{c}\text { No. of } \\
\text { Primary } \\
\text { Branches }\end{array}$ & $\begin{array}{l}\text { No. of } \\
\text { Nodes } \\
\text { per } \\
\text { plant }\end{array}$ & $\begin{array}{c}\text { No. of } \\
\text { clusters } \\
\text { per } \\
\text { plant }\end{array}$ & $\begin{array}{c}\text { No. of } \\
\text { Pods } \\
\text { per } \\
\text { plant }\end{array}$ & $\begin{array}{l}\text { No. of } \\
\text { seeds } \\
\text { per } \\
\text { pod }\end{array}$ & $\begin{array}{l}\text { Biologica } \\
\text { l yield } \\
\text { per plant } \\
\text { (g) }\end{array}$ & $\begin{array}{c}\text { Harve } \\
\text { st } \\
\text { Index } \\
(\%)\end{array}$ & $\begin{array}{c}\text { Test } \\
\text { weight } \\
\text { (g) }\end{array}$ & $\begin{array}{c}\text { Seed } \\
\text { yield per } \\
\text { plant (g) }\end{array}$ \\
\hline I & 46.36 & 82.43 & 3.92 & 12.22 & 6.19 & 43.73 & 2.41 & 22.86 & 22.02 & 11.26 & 4.94 \\
\hline II & 52.42 & 78.98 & 4.25 & 14.32 & 7.50 & 74.97 & 2.48 & 33.06 & 21.47 & 8.80 & 7.03 \\
\hline III & 44.70 & 54.32 & 2.91 & 10.71 & 5.93 & 41.08 & 2.42 & 20.31 & 21.67 & 9.62 & 4.34 \\
\hline IV & 41.00 & 57.17 & 4.00 & 9.27 & 6.13 & 40.47 & 2.33 & 21.30 & 29.98 & 14.30 & 6.33 \\
\hline V & 50.00 & 90.80 & 5.00 & 13.87 & 8.40 & 90.80 & 2.33 & 31.02 & 21.75 & 12.17 & 6.72 \\
\hline VI & 46.33 & 52.97 & 2.87 & 14.00 & 7.40 & 59.00 & 2.07 & 31.02 & 23.29 & 12.16 & 7.18 \\
\hline VII & 46.33 & 74.17 & 5.00 & 12.00 & 8.47 & 95.93 & 2.47 & 31.37 & 28.95 & 11.05 & 9.07 \\
\hline VIII & 49.00 & 95.87 & 4.00 & 16.00 & 6.67 & 39.27 & 2.00 & 31.30 & 14.74 & 6.41 & 4.59 \\
\hline IX & 41.00 & 76.20 & 4.93 & 16.93 & 7.20 & 84.93 & 2.47 & 34.83 & 11.67 & 8.04 & 4.04 \\
\hline
\end{tabular}


Table.7 Intra and inter cluster distance in soybean

\begin{tabular}{|c|c|c|c|c|c|c|c|c|c|}
\hline Clusters & I & II & III & IV & V & VI & VII & VIII & IX \\
\hline I & 80.15 & 258.69 & 259.64 & 175.21 & 306.51 & 193.56 & 430.95 & 270.5 & 343.62 \\
\hline II & & 105.45 & 470.2 & 490.07 & 192.86 & 202.38 & 201.17 & 225.49 & 202.78 \\
\hline III & & & 124.68 & 243.84 & 748.16 & 207.8 & 744.29 & 431.26 & 489.74 \\
\hline IV & & & & 0 & 493.55 & 221.3 & 507.92 & 659.09 & 636.67 \\
\hline V & & & & & 0 & 402.44 & 101.63 & 503.18 & 346.61 \\
\hline VI & & & & & & 0 & 363.74 & 320.51 & 336.75 \\
\hline VII & & & & & & & 0 & 650.06 & 438.75 \\
\hline VIII & & & & & & & & 0 & 182.95 \\
\hline IX & & & & & & & & & 0 \\
\hline
\end{tabular}

Fig.1 Clustering by Tocher's method

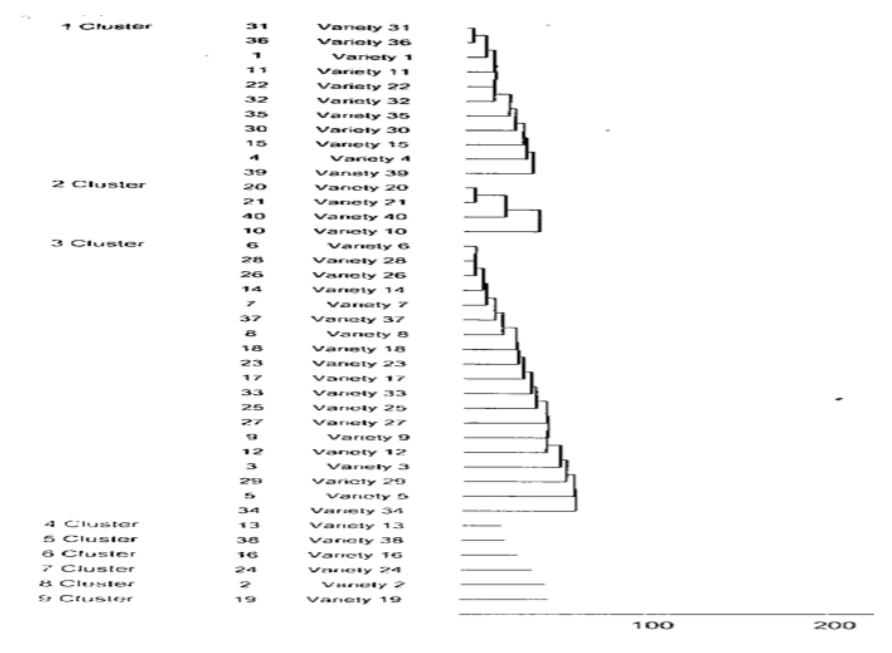

Fig.2 Contribution of different characters towards divergence

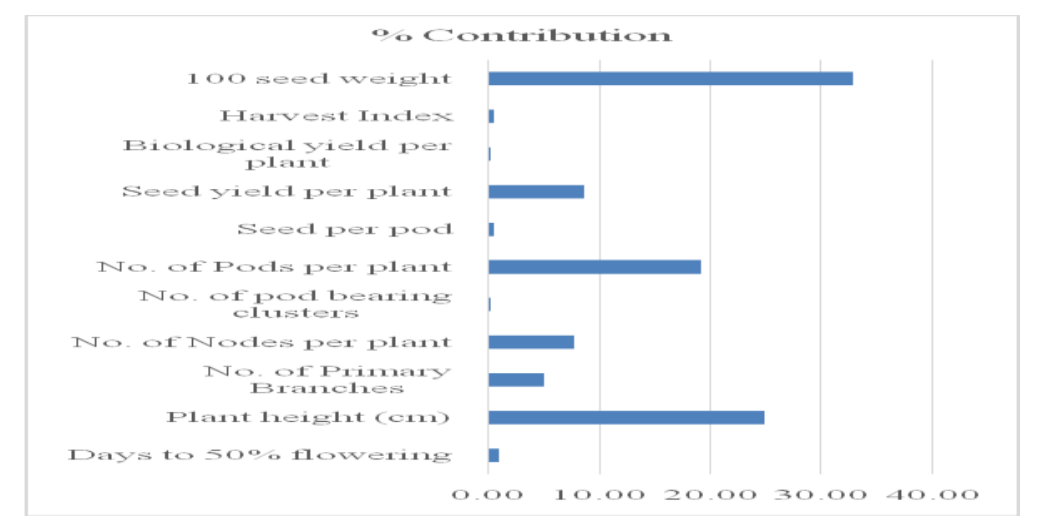

On the basis of Mahalanobis D2 statistics, the 40 soybean genotypes were grouped into 9 clusters. The maximum number of genotypes was included in cluster III comprising of 19 genotypes followed by cluster I with 11 genotypes, cluster II with 4 genotypes and 
clusters IV, V, VI, VII, VIII and IX with one genotype each indicating a high degree of heterogeneity among the genotypes. The maximum intra-cluster distance was registered for, cluster III (124.68), followed by cluster II (105.45) and cluster I (80.15).

The minimum intra cluster distance was observed in cluster IV, VII, VIII, IX (0.00). The inter-cluster distance (D2) was found maximum between cluster III and V (748.16) followed by the distance between cluster III and VII (744.29). Therefore, the genotypes present in these clusters should be given priority during selection of parents for further hybridization programmes.

It is concluded that Analysis of Variance showed significant differences for all characters under study at $1 \%$ and $5 \%$ Level of Significance. High estimates of GCV and PCV were observed for number of pods per plant followed by seed yield per plant. High heritability coupled with high genetic advance was recorded for plant height followed by test weight. Based on the relative magnitude of D2 values, the genotypes were grouped into nine clusters. Cluster III constituted maximum number of genotypes with 19 genotypes followed by cluster I. Maximum intra-cluster distance was found in cluster III followed by cluster II. Maximum inter-cluster distance (D2) was observed between cluster III and V. Test weight contributed maximum towards genetic divergence. Based on inter cluster distances and Per se performance, the genotypes TNAU 20051, MAUS 128 and KB 17 with test weight traits should be given top priority during selection of the genetically divergent parents in future breeding program.

\section{References}

Antalina. (1999). Recent research and industrial achievement for soybean in Japan. Proceeding Workshop on soy research. RIELT-JIRCAS, Japan.

Barh, A., Pushpwndra, Khulbe, R.K. and Joshi, M. (2014). A new source of genetic divergence for soybean improvement. African Journal of Agricultural Research. 9(1): 119-124.

Burton, G.W. (1952). Quantitative interaction in grasses. Proceedings of 6 th International Grassland Congress 1: 277-283.

Chandrawat K.S., Baig K.S., Hashmi S, Sarang D.H., Kumar A, Dumai P.K.(2017). Study on genetic variability, heritability and genetic advance in soybean. International Journal of Pure Applied Biosciences, 5(1): 57-63.

Johnson, H.W., Robinson, H.F. and Comstock, R.E. (1955). Estimation of genetic and environmental variability in soybean. Agronomy Journal. 47: 477483.

Karad S.R., Harer P.N., Kadam D.D. and Shinde R.B. (2005). Genotypic and phenotypic variability in soybean (Glycine max (L.) Merrill). Journal of Maharashtra Agricultural Universities; 30(3): 365- 367

Mahalanobis, P.C. (1936). On the generalized distance in statistics. National Institute of Sciences. India. 12: 49-55.

Rao, C.R. (1952). Advanced statistical methods in biometrical research. John Willy and Sons. New York.

Saurabh, S., Kamendra, S. and Pushpendra, (1998). Correlation and path coefficient analysis of yield and its components in Soybean (Glycine max L. Merrill). Soybean Newsletter. 25:67-70.

\section{How to cite this article:}

Rohitash Sharma and Gaibriyal M. Lal. 2020. Study of Genetic Divergence in Soyabean (Glycine max. (L.) Merrill) Germplasm. Int.J.Curr.Microbiol.App.Sci. 9(09): 2532-2537.

doi: https://doi.org/10.20546/ijcmas.2020.909.317 